\title{
1 Crossroads at Sea: Escalating Conflict in a Marine Protected Area in Malta
}

\section{$2 \underline{\text { Abstract }}$}

3 This article illustrates how the creation of a Marine Protected Area (MPA) in Malta is failing

4 to adequately include stakeholders in the configuration of conservation targets and measures,

5 leaving local fishers increasingly disempowered. Through a series of interviews and long-

6 term participatory observation, it has been found that the leaders who represent local fishers

7 are failing to communicate the MPA process to their community. Instead, they are using their

8 position in the MPA negotiations to subjugate and silence the fishing community in general

9 and trammel netters in particular. Moreover, in their support for the MPA, these community leaders reproduce the state's conservation discourse to pressure authorities to ban trammel net fishing, with whom they tend to be in competition. It is concluded that the state's narrow focus on ecology, the tight deadlines set out in the EU Habitats Directive, and the misrepresentation of the fishers, has characterised the process of creating this MPA. If artisanal livelihoods are not protected by conservation policies, fishers may regard conservation as a threat to their way of life, and resist policy measures. This compromises conversation efforts and can make the enforcement of the MPAs more expensive. This paper recommends a revision of the community consultation policies of the MPA to allow broader and more representative participation from the local community by encouraging engagement throughout the process as part of a consensual approach to effective marine conservation.

\section{Keywords}

21 Artisanal fishing, Mediterranean, European Union, Marine Protected Areas (MPAs), 22 Conservation Conflict, Disempowerment. 
The European Union's (EU) Habitats' Directive, enacted in 1992, obliges EU Member States to establish Special Area of Conservation (SACs) as marine protected areas within their territorial seas (EEC43/92 Art. 3). Given the jurisdictional rights of the Member States, the selection of candidate SAC sites, as well as the obligation to implement marine protection along Directive guidelines, is largely left up to national governments. The selection and implementation of Marine Protected Areas (MPAs), however, has triggered a number of problems in various EU Member States (Beunen and van Assche, 2013; Ferranti et al., 2010; Fleming and England, 2000; Paloniemi et al., 2015). Indeed, while being in line with the ecological obligations of the Habitats Directive, the choice of the areas is often highly political, especially in small-island states like Malta ${ }^{1}$, where size matters, and where land and marine use management is a delicate issue (Said et al. 2017).

Malta's maritime territory is congested with a plethora of activities (Figure 1), including transport (of cargo and passengers), trawling and industrial large-scale fishing, aquaculture and tuna-ranching, the bunkering and refuelling of ships, recreational diving, and small-scale, recreational fishing (Deidun et al., 2011; Said et al., 2017) Over the past years, the Maltese government has tried to control this congestion by allocating exclusive, special areas to most of these activities. However, small-scale fishing has not received the same spatial recognition in the promulgation of marine spatial policies. Consequently, small-scale fishing now has to pursue its recreational and artisanal activities (e.g. bottom line fishing, or the use of trammel nets, pots, and traps) in evershrinking waters. The designated MPAs, which are projected to encompass around $42 \%$ of the inshore fishing grounds, constitute another potential encroachment (Said et al., 2017).

1Malta, a $316 \mathrm{~km}^{2}$ archipelago in the centre of the Mediterranean, is inhabited by around half a million people and annually visited by around 1 million tourists, making it a very densely populated country. 
46 What is interesting about these areas, which have fishing hotspots for decades, is that their

47 selection has been based on the premise that they are 'geographically representative of good conservation status' (MEPA, 2010). Indirectly, their good conservation status 'implicates that the long-existing artisanal activity has been conducted in harmony what are now earmarked as priority habitats and species since the fishing activity has not degraded the pristine value of

51 these resources within the designated SACs.'(Said et al., 2017, p. 250). However, as this case study will signify, the hegemonic ideologies leading the MPA process seem to provide a different picture embedded in a narrowly-confined conservation narrative.

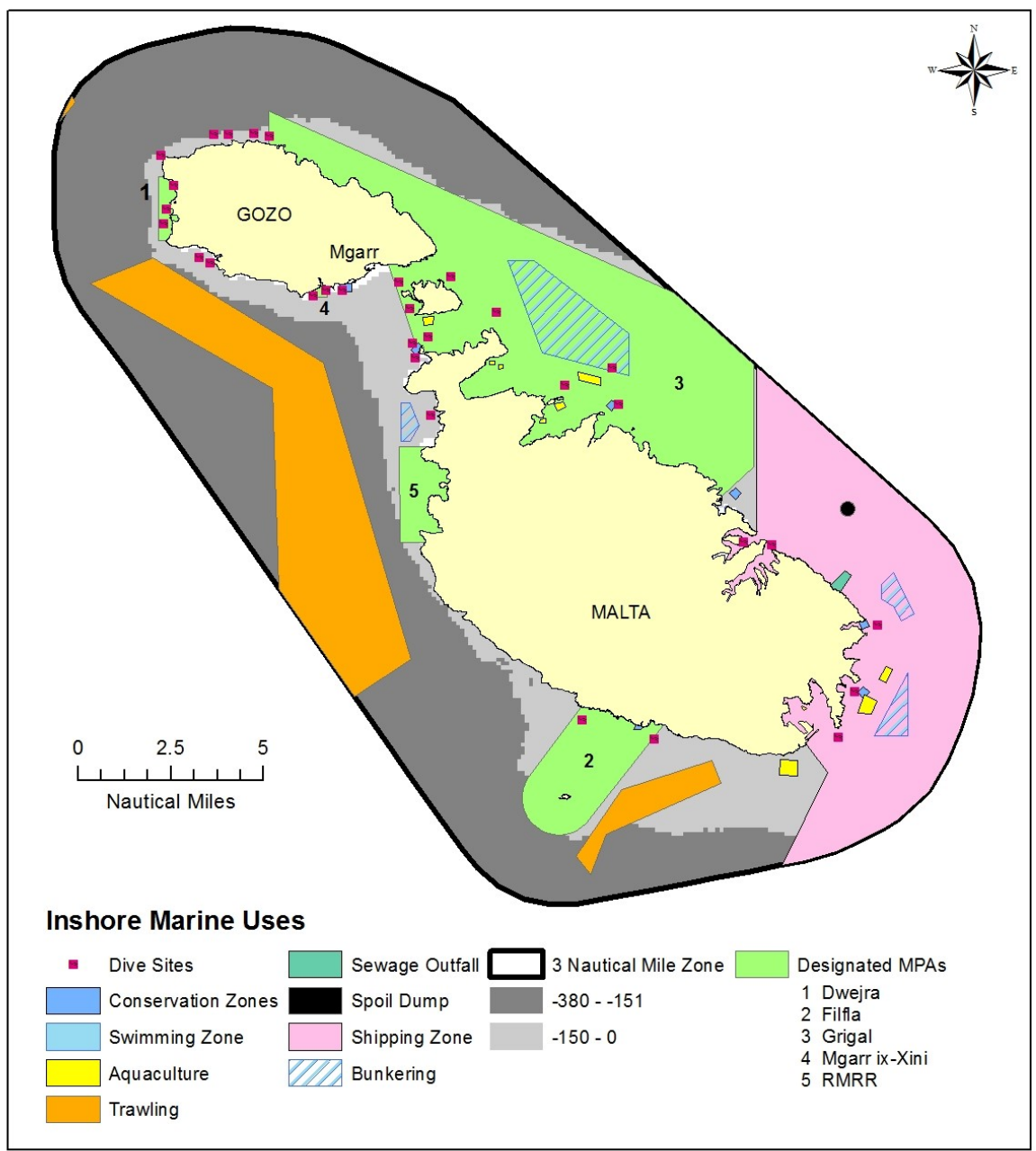

Malta's inshore areas, including the 5 designated Marine protected areas (Source: Said et al. 2017) 
The Maltese case indicates that MPAs should be understood as institutional systems that are implemented in socio-political settings, with political interests playing an important role in their inception, creation and implementation (Chuenpagdee et al., 2013). This view is consistent with the branch of human geography that questions the power relations in the production of space (Lefebvre, 1991; Sohn et al., 2013), as well as with political ecology, which sees environmental protection as constituted by social and political initiatives couched in scientific discourse and explanation (Forsyth, 2005).

This paper first describes how Malta is trying to meeting the obligations set out by the Habitats Directive by designating a number of MPAs in its territorial waters. Employing a constructive grounded theory methodology, which directs our attention to fishers' realities and the political-economic processes underpinning the designation of MPAs, we then focus on one exemplary MPA: the Rdum Majjiesa to Ras ir-Raћeb Marine Protected Area (RMRR MPA). In the results section, we provide a detailed account of how the MPA process is intensifying and aggravating the territorial disputes that already exist within the contested fishing grounds. In our concluding section, we then proceed to argue that the RMRR MPA contributes to research that shows that the way marine conservation comes to be perceived by user-stakeholders, including fishers, is tightly linked to the way initiatives to protect ecosystems are presented to them (Masud and Kari, 2015; Pietrzyk-Kaszyńska et al., 2012).

Studies have shown that fishers have been generally in favour of some form of management and protection of marine ecosystems due to the perceived benefits in the regeneration of fishing stocks (Barley Kincaid and Rose, 2014). However, research has also confirmed that fishers can quickly become resentful of MPAs, particularly if they are ignored, excluded, marginalised, and antagonised in the process of their implementation (Fabinyi, 2010, 2008; Jones, 2009). In Malta, the RMRR MPA has been approached exclusively through an ecological approach and employed inefficient modes of community 
representation. This, in turn, has turned the MPA into a site of intense conservation-conflict that is reconfiguring power-structures within the fishing community, threatening longexisting traditional fishing systems, and affecting the way fishers respond to the legitimacy of conservation efforts, which will ultimately determine the success or failure of the MPAs.

\section{1) Setting the Scene: Description of the national context}

After Malta became a member of the European Union in 2004, the Maltese government was given around 10 years to implement the Habitats Directive and designate Marine Protected Areas (MPAs) as Special Areas of Conservation (SACs), as part of the Natura 2000 network (EEC43/92 1992 Art 3 \& 4). The Government's first step was setting up a national legal framework that enabled it to ratify and meet its supranational obligations. This was achieved in 2006 through the enactment of Legal Notice 311, which laid the foundations for the protection of flora and fauna and commands the competent local authorities to issue plans and guidelines for the management and conservation of protected sites (L.N. 311 of 2006). Successively, the government, which has sole jurisdiction over the selection of the sites, designated five SACs around the Maltese islands (Figure 1), intended to afford maximum protection to species included in Annex I and II of the Habitats Directive. These include Posidonia oceanica, Pinna nobilis, Lithophaga lithophaga, and Astroides calycularis) as well as habitats like seagrass meadows, submerged caves, and rocky areas (MEPA and ICRAM, 2004). Although some of the management plans have been drafted, these are not yet finalized, and hence none of the designated MPAs are enforced to date.

The implementation of MPAs is a very complex and delicate affair since the Maltese territorial waters fall under various institutional authorities. The Environmental Resource Authority (ERA) is responsible for marine conservation; the Department for Fisheries and Aquaculture regulates fishing and aquaculture; Transport Malta controls maritime transport 
activities; and the Malta Tourism Authority is in charge of marine-based tourism. In fact, since the MPAs require new forms of coordination and cooperation between these organisations, their implementation has turned marine management into a convoluted zone of jurisdictions and responsibilities that overlap in unclear and uncertain ways.

Unsurprisingly, these governmental bodies sometimes enact policies that seem inherently contradictory. To give but one example, the national law SL 425.07, put in force in 2004, specifies that if owners of commercially-registered vessels want to keep their licence, at least once every three years they have to prove they have sold a specified amount of fish (CAP425.07). The need to meet this quota requires fishers to sustain the intensity of their fishing activities, and this somewhat clashes with the MPA's aim to conserve species and habitats. In other words, any environmental measure that reduces fishers' catches might jeopardise their position in the fishing sector.

One attempt to manage this complexity was made through the establishment of the Marine Protected Area Steering Committee. Yet, this Committee lacked the power to do anything except convene the various governmental entities to discuss matters pertaining to MPAs, and has, at the time of the fieldwork, been quite inactive as a committee (ERA Interview).

\section{2) The Rdum Majjiesa to Ras ir-Raheb MPA}

Although Legal Notice 311 was enacted in 2006, the first indication of a plan for the conservation of the Rdum Majjiesa to Ras ir-Raћeb area stretches back to an official technical report produced in 1991, which identified a total of 14 potential sites for marine conservation. This report, funded by the European Commission, was compiled as part of Malta's Structure Plan to present the potential for Marine Parks and Reserves. This Structure Plan was followed 
by the 'Coastal Area Management Programme' (CAMP 2000) which commissioned new ecological and biological studies of the zone and proposed a number of recommendations for protection (Pirotta and Schembri, 2000). Subsequently, in 2003, the MedMPA Project (MEPA and ICRAM, 2004), led by government-funded natural science experts, extended the first management plan, elaborating a proposed zoning scheme for the MPA that encompassed zones with varying levels of protection: 1) No Entry- No Take, 2) Entry No-take (guided access), 3) Entry No-Take (Free Access) and 4) General Protection as a buffer zone of the highly-restricted areas as illustrated in Figure 2.

In 2005, a public consultation document for the management framework for the marine environment in the RMRR MPA was issued (MEPA, 2005). Soon after, the RMRR MPA was the first of the five proposed MPAs to be declared as a Special Area of Conservation, forming part of the NATURA 2000 network in accordance with the Habitats Directive (EC 43/92 Art (3)). This MPA stretches along the north-western coast of Malta, and has a coastline inshore stretch $^{2}$ of around $11 \mathrm{~km}$ and a parallel offshore length of $5 \mathrm{~km}$ from Majjiesa to Raheb points, covering approximately $9.52 \mathrm{~km}^{2}$ of the marine area (MEPA, 2005).

In 2008, the RMRR MPA was nominated as a 'Site of Community Importance' (SCI) as part of the EU Natura 2000 Network of protected areas, and from that point, in line with the EU obligation, Malta had 6 years to establish conservation priorities for the area. 2014 marked six years since the selection of Rdum Majjiesa as a SCI and thus Malta's deadline to "establish priorities for the maintenance or restoration of this area" in line with Article 4 (4) of the Habitats' Directive. This means that the government, who appears to already have elapsed the deadline, is now in a rush to get the conservation objectives agreed and

\footnotetext{
${ }^{2}$ The coastal stretch is longer than the offshore perimeter since the former includes coastal inlets and a rugged coastline.
} 
154 how these will inform the objectives, and the concomitant management plan.

155

156

157

158

159

160

161

162

163

164

165

166

167

168

169

170

171

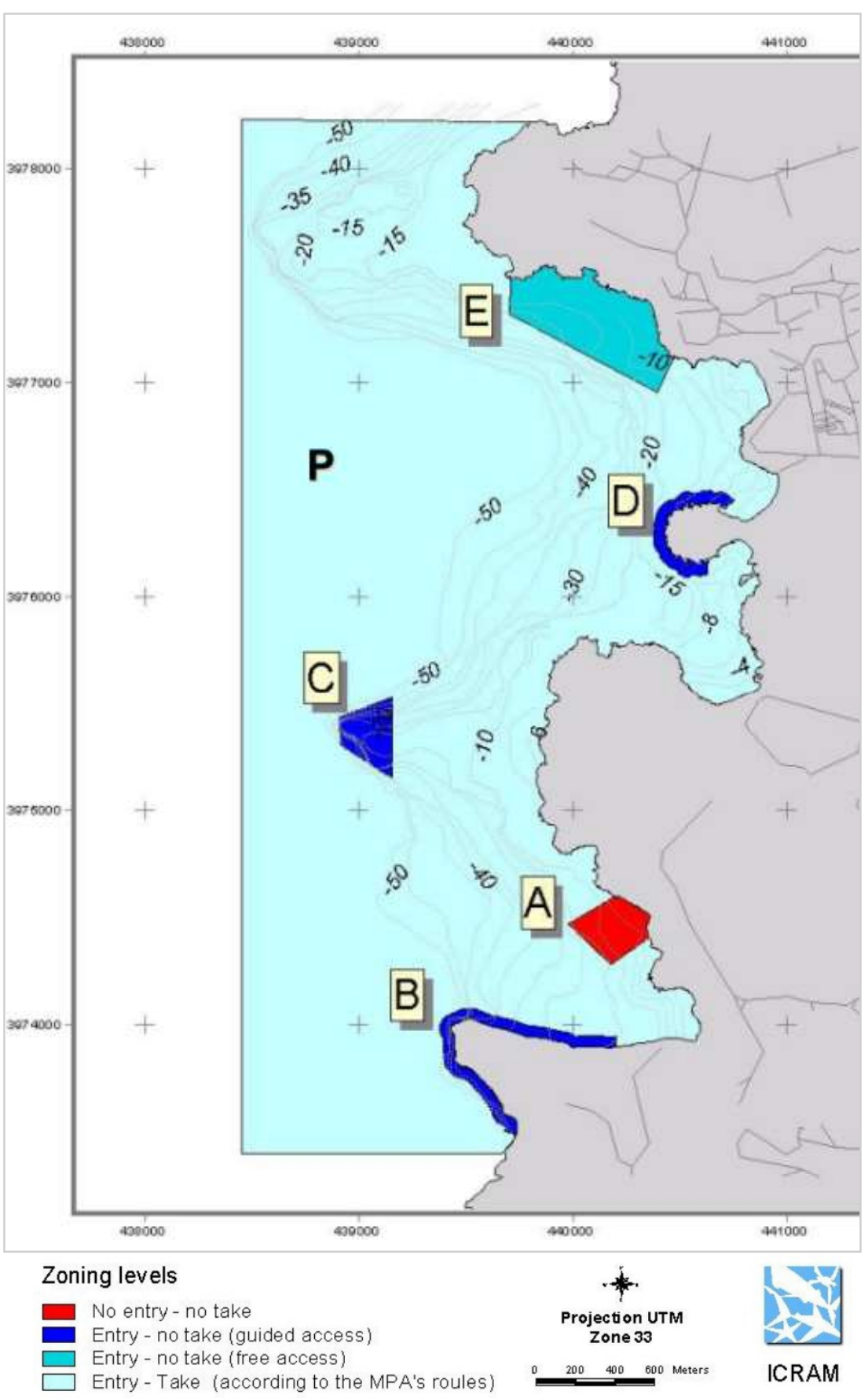

172

173

Figure 2: Zoning Plan for Rdum Majjiesa to Ras ir-Raheb MPA, Source University of Malta ${ }^{3}$

3 https://www.um.edu.mt/science/biology/staff/profpatrickschembri/empafish/rdum majiiesa to ras irraheb. 


\section{2) Materials and Methods}

Methodologically, this research followed the principles of Constructive Grounded Theory (CGT). CGT advocates a radically different relationship between theory and data. Traditional research models task researchers with the collection of enough data as is needed to (dis)prove a theory or a hypothesis. CGT, by contrast, urges a purely inductive approach until a 'saturation' of concepts is reached. Researchers are encouraged to employ a range of qualitative techniques, such as formal and informal interviews with local actors, participant observation, discourse analysis of published material and official meetings, in order to collect empirical data as it happens on the ground.

After every field session, we analysed our field-notes and audio recordings through NVIVO software, which facilitates the coding of different datasets to develop conceptual categories. The main conceptual categories were gathered through the constant comparison method (see Glaser 2007). These were then used to identify the issues and topics such as social processes of 'alienation' or 'marginalization' which, on the one hand, were central to understanding fishers' social context, and, on the other, we used as the building blocks for this paper's narrative. As coding progressed, we maintained a written records of our thought process by 'memoing' what we perceived as ground-breaking concepts. These 'memos', akin to the derivation of concepts and categories, were also included in the on-going analysis in the development of the theory. We also kept a record of significant quotes we encountered through formal and informal interviews, and incorporated them the interpretation of our data. In effect, fishers' voices nicely complemented the concerns and issues experiences by fishers in other contexts (e.g. Carothers 2015; Coulthard 2008; M. Glaser et al. 2010).

The end result of this process of data collection and analysis is a holistic portrait of the social relationships and political-economic processes occurring in a particular context. It 
also gives the researcher a solid grasp of the cultural categories and values that order the informants' worlds and shapes their behaviour. Since CGT provides rich substantive understandings of the field of study, it is ideal for unveiling knowledge in a field where either very little is known or where what is known has been solely achieved in a top-down manner that runs the risk of misunderstanding or misinterpreting what locals know, do, think, and want (Charmaz, 2006). The inductive nature of CGT makes it ideal for the present research, for it provides the necessary tools to develop a conceptual framework that identifies and explains the legitimacy crises at the heart of the MPA process of implementation. Drawing on Van Tatenhove (2011)'s work on legitimacy in marine governance issues, we provide a conceptual understanding of the inclusivity of stakeholder involvement, the transparency and accountability of the MPA policy processes.

Field research commenced in 2008, as part of the author's undergraduate studies and continued in 2013 and 2014 as part of doctoral research. Throughout these years, this author maintained close contact with fishers, building up knowledge through relations of trust between the informants and the researcher. In addition, since 2014, this ethnographic data was complemented with a series of formal in-depth interviews were held with (i) 15 local fishers from the Ġnejna fishing village (comprising $40 \%$ of the commercial fleet in the area), (ii) with fishers' representatives from the association Ghaqda Sajjieda Dilettanti Gnejna, literally translated as Ġnejna Artisanal Fishers Association (GAFA) (n=3), and (iii) with ERA, the authority responsible for the MPA $(n=3)$. These encounters with the main actors in the MPA arena were supplemented by insights obtained from extensive participatory observation, where one of the researchers joined local fishers as they went about their tasks at the fishing port, and accompanied them on fishing trips. These direct experiences yielded rich data related to subjects and issues where they are traditionally reticent, such as secretive behaviours and attitudes towards the state and their associations, and of course each other. 
224 They also gave privileged insight into sensitive matters that do not expose themselves easily through formal interviewing (MacMillan and Han, 2011). Given the sensitivity of the data collected, all measures were taken to ensure the full anonymity and confidentiality of the informants active in this research.

\section{3) Results}

\section{1) The Fishing Scenario: Territorial conflicts and fishing disputes}

Competition for fish resources in Malta's Northwest (NW) waters is rife due to the large number of commercial and recreational vessels contesting the same fishing grounds. According to local fishers, the grounds have sustained the fishing community for decades, and although fishing is not their main source of income, it is an important component of their lives. The urge to maintain connection with the sea through fishing is shared amongst all the commercial and recreational fishers of the area, and is especially evident in summer-time, when long days of sunny, calm weather call fishers out to the sea to pursue the promise of excellent catch. The NW fishing grounds are exposed to the prevailing north-westerly winds that hinder fishing activity, and thus on good days, fishers race to the best fishing grounds hoping to arrive ahead of other boats. The best spots are famous for different species including breams (Pagrus pagrus) melanura), squids (Galeorhinus galeus), octopi (Octopus vulgaris), bogues (Boops boops), dentex (Dentex dentex) and scorpionfish (Scorpaena scorfa), amongst other species.

The open-access nature of the fisheries allows fishers from different ports to deploy their gear in the same grounds, and this intensifies the competition for the resources. Given the competition, fishers are very wary of sharing details of their fishing activities. Extended periods of participant observation revealed a very strong sense of secrecy regarding the success or failure of fishing expeditions, the gears used and where the haul (or lack of it) occurred, fearing that others might capitalise upon this information. As a fisherman 
explained, "when you catch a lot of fish, fishers would be curious about where you made the catch, but it's not wise to reveal the discovery of a treasure." This environment of

251

252 competition and suspicion limits co-operation to one's immediate kin (basically brothers) and incredibly close friends.

Competition over fishing grounds and resources also occurs between or amongst different gear users including trammel nets, long-lines, pots and traps, and angling. Trammel netting, which involves the deployment of nets to catch demersal species ${ }^{4}$, is the most contentious activity, since it requires plenty of surface area and since, according to nontrammel net users such as recreational anglers and long-liners, 'trammel nets are like hoovers which wipe out all the fish'. This general belief puts trammel net fishers in a bad light, and clashes over the activity also escalate to ideological debates about its sustainability on different media platforms (Forum, 2014; TOM, 2011). The rivalry between and with trammel netters sometimes spirals into the deliberate damaging and stealing of trammel netting gear, typically targeted at those who "deploy truck-full of trammel nets" and leave no space for others to fish in these 'commons'.

Since 2012, conflict over resources has become further accentuated by the demarcation of a new trawling zone that has pushed large-scale fishing towards the perimeters of the inshore fishing grounds. Fishers have expressed criticism towards the fact that this trawling site is allegedly impacting the fish stocks in the inshore reefs. Although several fishers tried to reverse this by speaking to the authorities on various occasions, their attempts were unsuccessful since the implementation of the trawling zone, which benefits the industrial fishing sector, is in line with EU Mediterranean regulation (EC 1967/2006 Annex V).

\footnotetext{
${ }^{4}$ According to FAO definition, "A trammel net consists of two/three layers of netting with a slack small mesh inner netting between two layers of large mesh netting within which fish will entangle." http://www.fao.org/fishery/geartype/223/en
} 


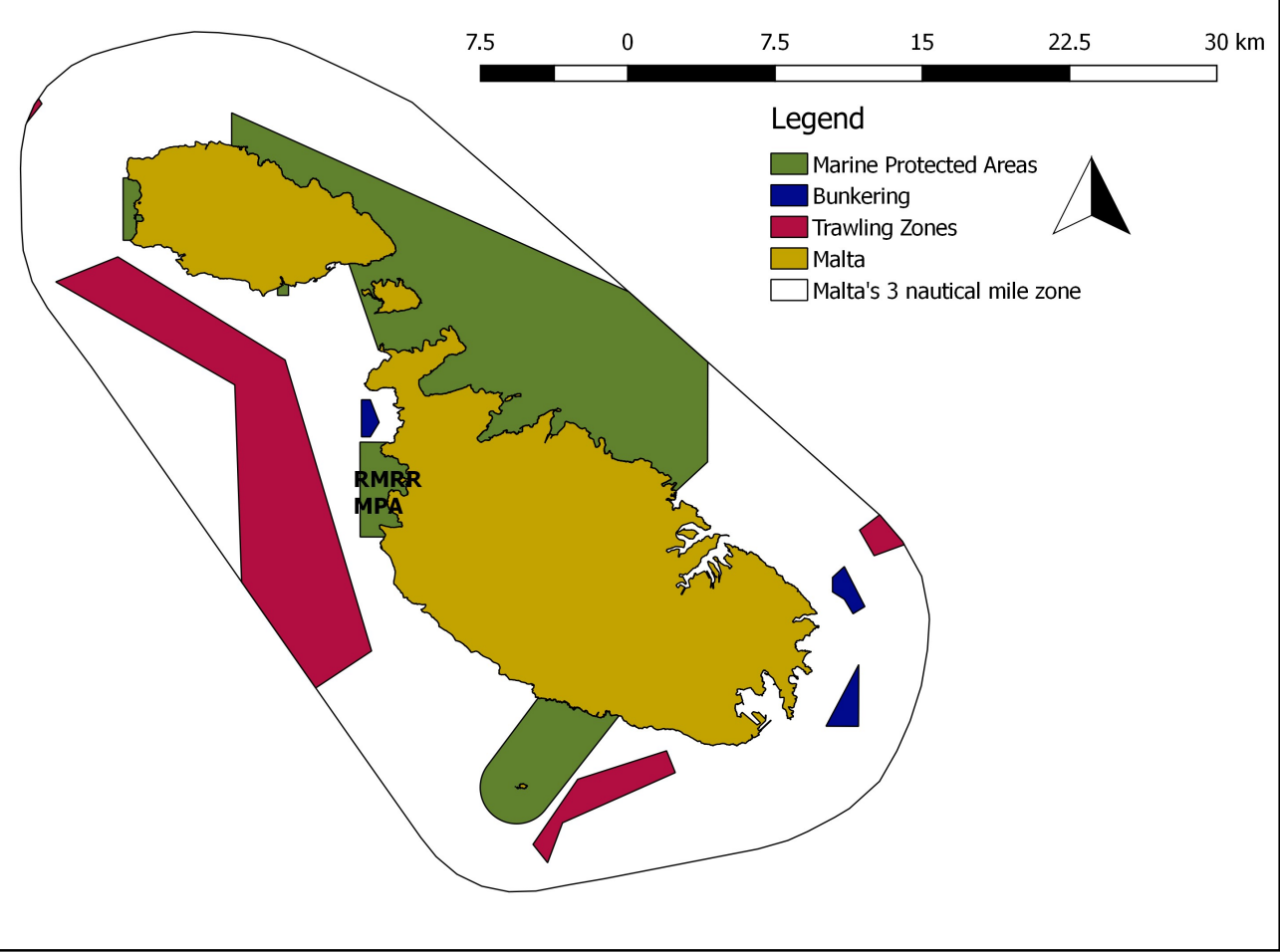

Figure 3: The practice of small-scale fishing within the North-western fishing village of Ġnejna is undergoing squeezing by the trawling and bunkering activities that take place within the long-established small-scale fishing grounds. The MPA which is earmarked within the $50-\mathrm{m}$ bathymetric contour could be an additional encroachment into these fishing grounds

This trawling site came along a long-existing bunkering zone which has, more than fifteen years ago, been established on a good fishing ground (Figure 3). Maltese bunkering zones, which provide shipping services, mainly fuel supply, to ships calling in Maltese territorial waters, are known to scour the seabed with their anchors, which allegedly affects the productivity of fishing grounds and unintentionally damage the fishing gear (Said et al., 2017). Although fishing is not restricted in the trawling and bunkering zones, fishers explained that fishing in these areas is risky for their gear can be easily damaged.

Already facing these spatial constraints, fishers have expressed concern regarding the RMRR MPA, which will potentially confine them further and intensify competition with other artisanal fishers. If the MPA restricts fishing activities or limits the type of fishing gear that can be used in the area, as indicated in the draft management plan, fishers will be left 
with a much smaller area in which to fish. The problem cannot be simply solved by having fishermen commute to other fishing zones. Not only would this be probably infeasible due to fuel costs involved, but fishers would be worried of entering areas already heavily used by trammel netters from other fishing ports, who would probably respond by damaging the gear of Ġnejna's fishers. The challenges brought about by this increasing congestion have shaped the contemplations and contestations of the majority of the fishers who, as will be detailed in the next section, have not been effectively incorporated in the consultation process of the MPA.

\section{2) Fishers and the MPA: Confusion, Clashes and Concerns}

The MPA has intensified the tensions amongst the fishers who depend on the inshore fishing grounds. This is because the local actors have been marginalised during the entirety of the process of the MPA's discussions. This section demonstrates how the MPA is riddled with communication and linguistic problems at the level of community representation. We describe how this is alienating fishers in general and trammel netters in particular, whose interests conflict with those of the fishers who represent them in front of the state. Trammel netters are worried they will be unable to protect their long-existing fishing traditions. Their fear is augmented by further marginalization at the hands of diving tourism occupying a new spatial niche in the area MPA.

\subsection{1) Communication and linguistic barriers are alienating fishers}

Long-term participatory observation with the fishing community indicates that the legal obligation for the MPA has not been properly and effectively communicated to the users of the area. For example, only one information meeting was held with the entire fishing community back in 2004. It was attended by the Environment Minister and led by natural science experts, who deployed scientific and legislative jargon that was not understood by the 
fishers. Shocked by the sudden arrival of what they perceived as a new environmental law constraining their fishing activities, the meeting spiralled out of control and, as one artisanal fisherman put it, "everyone was shouting and trying to make a point and there was no actual communication". On the same lines, the government report on the meeting noted that "as expected, the fishermen expressed their concern at having a restricted area where they could not enter and fish out of their own free will." (MEPA and ICRAM, 2004)" Following this event, stakeholder consultations, which were held to cover all the five MPAs, and not specifically the RMRR one, became more narrowly-focused on representatives of environmental NGOs, diving industries, and the fishers' co-operatives and associations, which do not fully represent small-scale and artisanal fishing interests (Said et al., 2017). This lack of bottom-up involvement with stakeholders was highlighted as a weakness in the analysis of the evaluation of the RMRR MPA follow-up in 2005 (MedMPA, 2005).

Unsurprisingly, the separation of most fishers from the participatory process has generated a sense of alienation from the RMRR MPA. Many feel uninformed and marginalized, and lack an understanding of the precise nature of Malta's legal obligations to the Habitats' Directive. They additionally seem ill-equipped to understand or challenge the concept of marine conservation within their fishing grounds, and have become suspicious of the whole thing. Their mistrust is deeply intertwined with the approach the authorities took to implement conservation. Aside from the fact that the stakeholder documents were not in Maltese, but in English, a language in which the fishers are not fluent, the scientific jargon used by experts has produced further ambiguities amongst the fishers about the actual objective of the MPA.

In lieu of effective and adequate explanation, fishers formed their own understanding of what the MPA is and what it was trying to achieve. In fact, the common understanding is that the MPA is about conserving fish stocks and not the protection of habitats and species as 
per legal clauses in the Habitats Directive. Fishers are perplexed with the zoning scheme (Figure 2) mentioned in the management plan, for there is no specific information on what will be controlled and how, and what types of fishing will be affected by the MPA. A dialogue with one of the fishers highlights a sense of ambiguity ${ }^{5}$ of what effects the MPA will have on fishing practices: "I think they (the authorities) want to ban all the fishing gear that has a direct contact with the seabed so we wouldn't even be able to lay a bogue trap, I think. They will only allow us to fish with the 'rixa' (trolling) I think... nothing can touch the seafloor... I think". These gaps in knowledge have created a shared concern among fishers who fear that the MPAs will restrict their ability to pursue further fishing in the area. One fisher, for example, indicated that the earmarked restricted zones are all-important fishing grounds - especially for trammel netters since "outside the zone, the area falls to around 90 fathoms ${ }^{6}$, making the use of trammel nets impossible”.

In effect, although no specific restriction have been placed yet, fishers engaging in trammel netting are the ones who feel most concerned, because they perceive the MPA a major threat to their activity and fear that they will be victimised by a conservation plan which they have no say over. Along with the other fishers, they feel marginalized by the authorities, and express feelings that they have been ignored and forgotten throughout the zoning process of the MPA. In fact, as one fisher highlighted, "the authorities did not care about us fishers and they never acknowledged us as stakeholders during the zoning process." Instead of voicing their concerns, most trammel netters have remained passive and cowed because they do not understand the MPA process and assume that the obligations that are being considered are incontestable. This partly stems from lack of communication about how

\footnotetext{
${ }^{6}$ One fathom is approximately 1.8 metres.
} 
the decision to have the RMRR area protected came about, and a misunderstanding over the role of the Maltese government in selecting MPA areas.

Aware that they are unable to influence or amend decisions they believe are made by higher, very powerful authorities at national and supranational level, fishers have failed to come together to discuss their complaints and plan the possibility for a collective response. Resigned to their fate, they have left the matter in the hands of their organisations, expecting them to advocate fishers' interests as best as they could. However, the continued failure to have the views and concerns of the entire fishers acted upon raises questions about the role and interests of the representatives in the political processes related to marine governance.

\subsection{2) Misrepresentation and marginalization of trammel netters}

The MPA consultative platforms are attended by spokespersons legitimately elected within fisher's co-operatives and associations. At Ġnejna, however, it would appear these spokespersons are not fully representing the needs and interests of most local fishers. The Ġnejna Artisanal Fishers Association (GAFA), which forms part of the Federation for Amateur Fishermen in Malta, was established in 1992 and has around 170 members. Its members hail from both the recreational and artisanal-commercial segments, for GAFA's legal statute obliges it to advocate the rights of all Gंnejna fishers and speak on issues pertaining to the area's infrastructural arrangements, such as boathouses and slipways. However, the executive committee of GAFA is dominated by fishers who use long-lines, and who, due the nature of their activity, are in open, competition with trammel netters. The result is that trammel netters have effectively been excluded from the conversation about the RMRR MPA.

Officially, GAFA is openly supportive of the implementation of the MPA. That said, its executive committee adopted this stance without the full consent of their members, 
especially those fishers involved in trammel netting (around $50 \%$ of the commercial fishers from the Ġnejna village and other nearby fishing ports). In one of the written consultations, the Federation representing GAFA has expressed that they agree "to stop all kinds of net laying, trawling and other deep-water non-selective gear and simultaneously request "that deep water long line fishing be permitted in this area"(MEPA and ICRAM, 2004). Naturally, the banning of the trammel nets will benefit those engaging in long-lining, hence it can be the case that the fishers' representatives are adopting a conservation discourse to achieve benefits for themselves by supporting a ban on trammel nets in the fishing grounds. For example, during one of the interviews one representative stated that, "The sea is never given a break here, they should stop the trammel nets; at least for some years to give some time for the fish to recover". Ironically, most of the trammel fishers are not aware of the GAFA's position and many have even expressed a sense of satisfaction towards their spokespersons who they firmly believe are doing their best to advocate their interests. Many fishers also feel that their representatives, who can speak English, are better prepared to deal with conservation's ecological and legal language. As one fisher indicated, "GHSD $\dot{G}$ has people capable enough to represent and fight for the rights of fishers."

Information gained in government-organized meetings ${ }^{7}$ appears to have been retained within the executive circles of the GAFA and the Federation, and not communicated to the members. This allows the GAFA leadership to maintain control over the fishers' discourse. Their monopoly over communication has enabled leaders to, on the one hand present and direct policy in whichever way they deem appropriate, and on the other hand claim to represent all fishers, obscuring the need for a more thorough system of stakeholder inclusion. Instead of building a communicative bridge between the fishers and the authorities, the

7 Such meetings held by the local authorities include the implementation of the 'underwater trail' within the RMRR in 2013, and 'the symposium on sustainable diving in marine reserves' in 2014, amongst others. 
406 GAFA has implicitly, perhaps not deliberately, created a restraining barrier that has

407 reinforced the fishers' opposition towards the MPA. Indirectly, this barrier has also hindered

408

409

410

411

412

413 the building-blocks of knowledge co-production between the entire fleet and MPA experts.

Only one fisher showed some informed concern over the fact that GAFA has not provided support to the trammel net users. In fact, in 2008, he attempted to seek answers directly from the authorities by sending a letter to the Maltese Prime Minister. But the meetings which were scheduled with ERA got him nowhere, and he retreated feeling helpless and further alienated. Our research suggests that the system of participatory governance chosen for this projects is suffocating rather than enticing stakeholder engagement. It is additionally allowing the needs and interests of the trammel netters to be subjugated by those in powerful positions who wish to capture the process to further their pecuniary advantage.

\subsection{3) Dive tourism - a new exogenous threat?}

If the system of representation does not change, fishers will remain alienated and detached from the whole process that determines their future in the marine area. At this delicate juncture, another development threatens to further destabilise the MPA process. In order to finance the NATURA 2000 site, the launching of diving tourism has been proposed as part of a potential revenue-generation scheme to monitor the MPAs (MEPA, 2013). Although diving is not yet popular in this marine area, its promotion for the diving tourism niche raises important questions on the ramifications of such a proposal. Firstly, if not properly monitored, diving can damage protected sensitive habitats due to excessive kicking, a phenomenon reported in various situations (Hayes et al. 2017; Ku and Chen 2013), thereby contradicting the main obligation of the Habitats' Directive to maintain and restore the conservation status of protected species and habitats. 
Secondly, and more pertinent to the present paper, is that diving tourism would add yet another economic activity into this long-established and congested fishing ground. If any plans for tourism investments are introduced without sufficient exchange of ideas with the fishers, the MPA as a tourist venue would further intensify the displacement of fishers. This would likely consolidate them as victims of environmental inequities and injustices due to reduced access to fishing areas in the creation of nature reserves for ecotourism purposes, as has been reported in similar situations (Duffy, 2002; Fabinyi, 2008; Naar and Mahenge, 2014).

\section{4) Discussion}

This paper documents the overlooked socio-political dynamics involved in the implementation of one MPA in Malta. It shows that when MPAs are approached and developed from a strictly ecological perspective, the equally-important social, economic and cultural aspects of the area are ignored. Un-factored into the policy processes, the governance of the stakeholders and their relations with each other and the state can spiral out of control (Blount and Pitchon, 2007). The human dimension can quickly become a rebellious force that can either seriously obstacle conservation or hijack it to further personal interests and powerstruggles. Concretely, this article highlights the authorities' inability to factor in the social realities of fishers' disputes, because their natural-scientific approach is simply too narrow (Degnbol et al., 2006), and unable to recognise the MPA's social, cultural, and political aspects.

A dangerous domino effect thus ensues. The government's ecologically-biased stance has produced a half-hearted strategy of community consultation that is not extensive or

452 flexible enough to account for the diversity of the fishing community. The error lies in that any communication of information between state and community must go through the representatives of the fishing community. These spokespersons have interests and agendas 
other than simply representing the community. They find that this new-found control over information helps them to negotiate policy in a way that secures their personal goals and interests (Van Tatenhove, 2013). These vested objectives, which hinge around the phasing out of trammel netting, require the subjugation and silencing of the wider fishing community and its collective knowledge. Most fishers, thus, become trapped in situation of alienation and mistrust towards the MPA. Finally, feeling disempowered in an 'impossible' situation created in the name of 'conservation', fishers start directing their anger not at the government, which they hold powerless in front of the EU, or their representatives, who they seem to have complete trust in, but at conservation in general.

We argue that if the systems of representation do not change soon, all the major stakeholders involved in the project including the state, fishers, and conservation itself, will emerge as definite losers. In Malta, as elsewhere, fishers are set to become the main victims of the MPA, as access to fishing areas becomes limited (Chen et al., 2015), become squeezed between conservation zones and industrial fishing (Begossi et al., 2011), or displaced by new MPA economic niches, such as diving tourism (Fabinyi, 2008). Despite the continuous urge towards the need of participatory attempts for MPA designations and implementations (Agardy et al., 2011; Chuenpagdee et al., 2013; Guenette et al., 2000; Jones, 2009) marginalization and disempowerment of fishers seems to be a lingering phenomenon (Charles and Wilson, 2009; Fox et al., 2012; Hattam et al., 2013; van Assche et al., 2012).

If fishers remain unprotected, they are likely to start actively resisting the MPA conservation policy initiative. In similar situations elsewhere, resistance has evolved into protest fishing and incompliance towards the conservation objectives (Ferranti et al., 2010; Stoll-Kleemann, 2001). Consequently MPAs either become very costly to monitor and enforce, or remain mere paper parks with no actual success (Silva and Lopes, 2015). This might damage the state's relationship with the EU, for it would have ultimately failed to 
comply with EU Directives. A foundered MPA could, at best, embarrass the government in front of its EU partners, or, at worst, result in fines and sanctions that translate into wider political repercussions.

This case study adds to the plea for adopting an all-encompassing approach to understand the realities of marine conservation from the bottom-up (Kidwai et al., 2016). Better consultative platforms not only increase the empowerment of fishers in decisionmaking, but also allow for the articulation of the social objectives of fishing in MPAs in a way that safeguards the needs of long-established users (Guenette et al., 2000; Jentoft et al., 2012; Jentoft and Knol, 2014). It moreover engenders a sense of MPA ownership and stewardship amongst the fishers (Ferse et al., 2010; Glaser et al., 2010), and increases the legitimacy of marine governance (Van Tatenhove, 2011).

\section{5) Conclusions and Recommendations}

The establishment of the Special Areas of Conservation (SAC) in marine areas follows Malta's obligation to ratify the Habitats' Directive Council Directive (EC/92/43). However, there is still uncertainty as to how the objectives of the MPA are to be reached. This article, focusing on one of Malta's MPAs, explains how the overlaying of a conservation designation over an already contested and limited space is likely to intensify the pre-existing fishing disputes.

The inadequate attention towards the interplay of the local uses is perilously close to alienating and marginalising local fishers, who are feeling increasingly powerless and polarized. As a result, the inescapable EU-set deadlines might lead to a peremptory MPA that might entice more confrontation and incompliance by the fishing sector, especially if the fishers lose their fishing rights. Whether these plans will develop into physical exclusion of local fishers from the RMRR MPA is yet to be revealed. However, as matters stand, the future of the fishers looks bleak. This is because the MPA decision-making process is 
creating problems related to the reduced power of negotiation, leaving outright resistance and opposition as the only available options and thus inevitably polarising the fishing arena.

This article argues for improved stakeholder inclusion policies in marine conservation, with specific reference to the RMRR MPA. Fishers are a heterogeneous group, with differing, oftentimes competing, interests. This spectrum of voices needs to be recognized and consulted through the entirety of the MPA implementation process, and not just at the very end, which, at best, creates the impression the community has been consulted as a courtesy, and at worst, turns conservation into an outside imposition. If the MPA's implementation is harmonised to its ecological and social context, it would smoothen the path for policy-makers in engendering willingness of co-operation amongst fishers. If not, the MPA will alienate and antagonise local users, which end up being sucked into tensions themselves. In this particular situation, the authorities, riding on bad conservation, are heading directly down that path, forgetting that conservation is, mostly, conversation.

\section{References}

1967/2006, E., n.d. Council Regulation (EC) No 1967/2006 [WWW Document]. URL http://eurlex.europa.eu/LexUriServ/LexUriServ.do?uri=OJ:L:2006:409:0011:0085:EN:PDF (accessed 7.16.14).

2006, L.N. 311 of, 2006. L.N. 311 of 2006 - Protection of Flora, Fauna and the Natural Environment.

Agardy, T., di Sciara, G.N., Christie, P., 2011. Mind the gap: Addressing the shortcomings of marine protected areas through large scale marine spatial planning. Mar. Policy 35, 226-232. doi:10.1016/j.marpol.2010.10.006

Barley Kincaid, K., Rose, G. a., 2014. Why fishers want a closed area in their fishing grounds: Exploring perceptions and attitudes to sustainable fisheries and conservation 10 years post closure in Labrador, Canada. Mar. Policy 46, 84-90. doi:10.1016/j.marpol.2014.01.007

Begossi, A., May, P.H., Lopes, P.F., Oliveira, L.E.C., da Vinha, V., Silvano, R. a. M., 2011. 
Compensation for environmental services from artisanal fisheries in SE Brazil: Policy and technical strategies. Ecol. Econ. 71, 25-32. doi:10.1016/j.ecolecon.2011.09.008

Beunen, R., van Assche, K., 2013. Contested delineations: Planning, law, and the governance of protected areas. Environ. Plan. A 45, 1285-1301. doi:10.1068/a45284

Blount, B.G., Pitchon, A., 2007. An Anthropological Research Protocol for Marine Protected Areas: Creating a Niche in a Multidisciplinary Cultural Hierarchy. Hum. Organ. 66, 103-111.

CAP425.07, 2014. Subsidiary legislation 425.07 fishing vessels regulations 1-20.

Carothers, C., 2015. Fisheries privatization, social transitions, and well-being in Kodiak, Alaska. Mar. Policy 61, 313-322. doi:10.1016/j.marpol.2014.11.019

Charles, A., Wilson, L., 2009. Human dimensions of Marine Protected Areas 6-15.

Charmaz, K., 2006. Constructing Grounded Theory, A Practical Guide Through Qualitative Analysis, Book. Sage Publications.

Chen, C.-T., Lin, H.-J., Ko, T.-T., Cheng, H.-C., Wright, J.R., Chang, Y.-C., 2015. Spatial resource allocation modeling for marine protected areas design: The case of Kaomei coastal wetland. Ocean Coast. Manag. 110, 46-56. doi:10.1016/j.ocecoaman.2015.03.007

Chuenpagdee, R., Pascual-ferna, J.J., Szelianskzky, E., Alegret, J.L., Fraga, J., Jentoft, S., 2013. Marine protected areas : Re-thinking their inception. Mar. Policy 39, 234-240.

Coulthard, S., 2008. Adapting to environmental change in artisanal fisheries-Insights from a South Indian Lagoon. Glob. Environ. Chang. 18, 479-489. doi:10.1016/j.gloenvcha.2008.04.003

Degnbol, P., Gislason, H., Hanna, S., Jentoft, S., Raakjær, J., Sverdrup-jensen, S., Clyde, D., 2006. Painting the floor with a hammer: Technical fixes in fisheries management. Mar. Policy 30, 534-543. doi:10.1016/j.marpol.2005.07.002

Deidun, a., Borg, S., Micallef, a., 2011. Making the Case for Marine Spatial Planning in the Maltese Islands. Ocean Dev. Int. Law 42, 136-154. doi:10.1080/00908320.2011.542108

Duffy, R., 2002. A Trip Too Far: Ecotourism, Politics and Exploitation, 1st editio. ed. Routledge. 
EEC43/92, n.d. Council Directive 92/43/EEC of 21 May 1992 on the conservation of natural habitats and of wild fauna and flora.

Fabinyi, M., 2010. The Intensification of Fishing and the Rise of Tourism: Competing Coastal Livelihoods in the Calamianes Islands, Philippines. Hum. Ecol. 38, 415-427. doi:10.1007/s10745-010-9329-z

Fabinyi, M., 2008. Dive tourism, fishing and marine protected areas in the Calamianes Islands, Philippines. Mar. Policy 32, 898-904. doi:10.1016/j.marpol.2008.01.004

Ferranti, F., Beunen, R., Speranza, M., 2010. Natura 2000 in Italy and the Netherlands. J. Environ. Policy Plan. 12, 293-314.

Ferse, S.C. a., Máñez Costa, M., Máñez, K.S., Adhuri, D.S., Glaser, M., 2010. Allies, not aliens: increasing the role of local communities in marine protected area implementation. Environ. Conserv. 37, 23-34. doi:10.1017/S0376892910000172

Fleming, B., England, N., 2000. Conflict resolution in the Humber Estuary Natura 2000 protected area.

Forsyth, T., 2005. The Political Ecology of the Ecosystem Approach for Forests pp. 165-176 in Sayer, J. and Maginnis, S. (eds), in: Forests in Landscapes: Ecosystem Approaches to Sustainability. Earthscan, pp. 165-176.

Forum, M.F., 2014. Malta Fishing Forum 1-26.

Fox, H.E., Mascia, M.B., Basurto, X., Costa, A., Glew, L., Heinemann, D., Karrer, L.B., Lester, S.E., Lombana, A. V., Pomeroy, R.S., Recchia, C. a., Roberts, C.M., Sanchirico, J.N., Pet-Soede, L., White, A.T., 2012. Reexamining the science of marine protected areas: linking knowledge to action. Conserv. Lett. 5, 1-10. doi:10.1111/j.1755-263X.2011.00207.x

Glaser, B.G., 2007. All is data. Grounded Theory Rev. An Int. J. 6, 1-22.

Glaser, M., Baitoningsih, W., Ferse, S.C.A., Neil, M., Deswandi, R., 2010. Whose sustainability? Top-down participation and emergent rules in marine protected area management in Indonesia. Mar. Policy 34, 1215-1225. doi:10.1016/j.marpol.2010.04.006 
Guenette, S., Chuenpagdee, R., Jones, R., 2000. Marine Protected Areas with an Emphasis on Local Communities and Indigenous Peoples: a review 8.

Hattam, C.E., Mangi, S.C., Gall, S.C., Rodwell, L.D., 2013. Social impacts of a temperate fisheries closure: understanding stakeholders' views. Mar. Policy 1-10. doi:10.1016/j.marpol.2013.09.005

Jentoft, S., Knol, M., 2014. Marine spatial planning : risk or opportunity for fisheries in the North Sea $? 1-16$.

Jentoft, S., Pascual-Fernandez, J.J., de la Cruz Modino, R., Gonzalez-Ramallal, M., Chuenpagdee, R., 2012. What Stakeholders Think About Marine Protected Areas: Case Studies from Spain. Hum. Ecol. 40, 185-197. doi:10.1007/s10745-012-9459-6

Jones, P.J.S., 2009. Equity, justice and power issues raised by no-take marine protected area proposals. Mar. Policy 33, 759-765. doi:10.1016/j.marpol.2009.02.009

Kidwai, S., Fanning, P., Ahmed, W., Tabrez, M., Zhang, J., Khan, M.W., 2016. Practicality of marine protected areas - Can there be solutions for the River Indus delta? Estuar. Coast. Shelf Sci. 183, 349-359. doi:10.1016/j.ecss.2016.09.016

Lefebvre, H., 1991. The social production of space, First. ed. Wiley-Blackwell.

MacMillan, D.C., Han, J., 2011. Cetacean By-Catch in the Korean Peninsula-by Chance or by Design? Hum. Ecol. 39, 757-768. doi:10.1007/s10745-011-9429-4

Masud, M.M., Kari, F.B., 2015. Community attitudes towards environmental conservation behaviour: An empirical investigation within MPAs, Malaysia. Mar. Policy 52, 138-144. doi:10.1016/j.marpol.2014.10.015

MedMPA, 2005. Evaluation and follow-up of activities carried out within the framework of the MedMPA.

MEPA, 2013. Study on Financing requirements for local marineprotected areas and self-financing recommendations. 
MEPA, 2010. Four New Marine Protected Areas [WWW Document]. Malta Environ. Plan. Auth. URL https://www.mepa.org.mt/outlook5-article2 (accessed 3.12.14).

MEPA, 2005. Rdum Majjiesa to Ras ir-Raheb Marine Protected Area - A Management Framework for the Marine Environment.

MEPA, ICRAM, 2004. Regional Project for the Devlopment of Marine and Coastal Protected Areas in the Mediterranean Region (MedMPA), Rdum Majjiesa to Ras ir-Raheb Cave Elaboration of a Management Plan. European Commission.

Naar, N., Mahenge, J., 2014. Finding a middle ground - Conservation challenges among stakeholders in coastal Tanzania. Anthropol. Today 30, 9-14.

Paloniemi, R., Apostolopoulou, E., Cent, J., Bormpoudakis, D., Scott, A., Grodzińska-Jurczak, M., Tzanopoulos, J., Koivulehto, M., Pietrzyk-Kaszyńska, A., Pantis, J.D., 2015. Public Participation and Environmental Justice in Biodiversity Governance in Finland, Greece, Poland and the UK. Environ. Policy Gov. n/a-n/a. doi:10.1002/eet.1672

Pietrzyk-Kaszyńska, A., Cent, J., Grodzińska-Jurczak, M., Szymańska, M., 2012. Factors influencing perception of protected areas-The case of Natura 2000 in Polish Carpathian communities. J. Nat. Conserv. 20, 284-292. doi:10.1016/J.JNC.2012.05.005

Pirotta, K., Schembri, P.J., 2000. CAMP Malta - Marine Conservation Area.

Said, A., MacMillan, D., Schembri, M., Tzanopoulos, J., 2017. Fishing in a congested sea: What do marine protected areas imply for the future of the Maltese artisanal fleet? Appl. Geogr. 87. doi:10.1016/j.apgeog.2017.08.013

Silva, M.R.O., Lopes, P.F.M., 2015. Each fisherman is different: Taking the environmental perception of small-scale fishermen into account to manage marine protected areas. Mar. Policy 51, $347-$ 355. doi:10.1016/j.marpol.2014.09.019

Sohn, C., Christopoulos, D., Koskinen, J., 2013. Geography is more than distance! The effects of borders and territorality over policy networks, in: Applications of Social Network Analysis. 
634 TOM, 2011. Trammel nets still reign supreme. Timesofmalta.com.

635 van Assche, K., Bell, S., Teampau, P., 2012. Traumatic Natures of the Swamp: Concepts of Nature in 636 the Romanian Danube Delta. Environ. Values 21, 163-183.

637 doi:10.3197/096327112X13303670567297

638 Van Tatenhove, J.P.M., 2013. How to turn the tide: Developing legitimate marine governance

639 arrangements at the level of the regional seas. Ocean Coast. Manag. 71, 296-304.

$640 \quad$ doi:10.1016/j.ocecoaman.2012.11.004

641 Van Tatenhove, J.P.M., 2011. Integrated marine governance: Questions of Legitimacy. Mast 10, 87642 113.

643 